\title{
Biofilms bacterianos
}

\section{Bacterial biofilms}

\author{
Julio Nazar C.
}

\section{INTRODUCCIÓN}

Las bacterias existen en la Naturaleza bajo dos formas o estados: a) bacterias planctónicas, de libre flotación, y b) bacterias biofilm, en colonias de microorganismos sésiles. Desde los tiempos de Koch, bacteriólogos y clínicos se han abocado al estudio de los gérmenes planctónicos, libremente suspendidos, y descritos en base a sus características de desarrollo en medios de cultivos adecuados.

Esto se ha debido, entre otras razones, al hecho que la investigación de los biofilms bacterianos es singularmente más difícil que aqué Ila respecto a las bacterias planctónicas. Desafortunadamente, este enfoque centrado en el desarrollo de estas últimas en cultivos de laboratorio, una condición que tiene escasa relación con los ambientes microbianos verdaderos, ha limitado la comprensión respecto a las interacciones entre bacterias y huéspedes ${ }^{1,2}$.

Tan sólo una muy pequeña fracción de las bacterias se halla en forma planctónica o de libre flotación, y las bacterias biofilm son diferentes a las planctónicas. Se postula que el $99 \%$ de todas las células bacterianas existen en calidad de biofilms, y tan sólo $1 \%$ vive en estado planctónico ${ }^{3-5}$.

La adhesión bacteriana a superficies ha sido reconocida por varias décadas. Ya por los años '70, los microbiólogos plantearon que, probablemente, la mayor parte de las bacterias en la Naturaleza existía en estado de biofilm. Sin embargo, la terapia de la mayoría de las infecciones humanas continúa aún basada en el estudio de las minorita- rias bacterias planctónicas libre flotantes. Los biofilms se crean cuando las bacterias libre flotantes perciben una superficie, se adhieren a ella y, a continuación, elaboran señales químicas para coordinar diferenciación y formación de estructura, incluyendo el desarrollo de una cubierta polisacárida protectora ${ }^{6}$.

Los gérmenes pueden crear condiciones para formar biofilms casi en cualquier ambiente líquido. La interfase sólido-líquida entre una superficie y un medio acuoso (vgr: agua, sangre) proporciona un entorno ideal para la fijación y crecimiento de microorganismos ${ }^{7}$. Por consiguiente, los biofilms son ubicuos en la Naturaleza y se encuentran prácticamente en todo cuerpo natural de agua en el mundo 8 .

Es así como cotidianamente debemos convivir con ellos: el limo o película que recubre un jarrón en el que se ha tenido flores, el material resbaladizo que tapiza las piedras de los lechos de los ríos, los cascos de los barcos o la superficie interna de una tubería. Oro ejemplo cotidiano de biofilm lo constituye la placa dental. Diariamente debemos combatir la película de bacterias que cubre la superficie dental para evitar el desarrollo excesivo de microorganismos que puede provocar un deterioro del esmalte 2,9 .

Los biofilms bacterianos representan una antigua estrategia de supervivencia procariótica. Esto debido a que las bacterias logran ventajas significativas al proporcionarles los biofilms protección frente a fluctuaciones medioambientales de humedad, temperatura y $\mathrm{pH}$, al igual que concentrando nutrientes y facilitando la eliminación de desechos. 
Registros efectuados en fósiles revelan que procariotes han estado viviendo en biofilms por más de tres billones de años ${ }^{10}$.

La capacidad de formar biofilm no parece restringirse a ningún grupo específico de microorganismos y, en la actualidad, se considera que bajo condiciones ambientales adecuadas la inmensa mayoría de las bacterias, independiente de la especie, puede existir dentro de biofilms adheridos a superficies en una interfase sólido/ líquida, incluyendo organismos importantes en enfermedades otorrinolaringológicas, tales como $P$ aeruginosa, Hinfluenzae, S pneumoniae, Kebsiella y $S$ aureus ${ }^{2,8-11}$. Esta adhesión a una superficie húmeda, ya sea inerte o viviente, es de carácter irreversible, esto es, el biofilm no logra ser removido mediante lavado suave ${ }^{1,3-5,9,10,12,13}$.

\section{DEFINICIÓN E HISTORIA}

En 2002, Donlan efectuó una descripción ampliamente aceptada de un biofilm, estableciendo que es "una comunidad microbiana sésil, caracterizada por células que están adheridas irreversiblementea un substrato o interfase, o unas con otras, encerradas en una matriz de sustancias poliméricas extracelulares que ellas han producido, y exhiben un fenotipo alterado en relación con la tasa de crecimiento y trascripción génica"1.

Van Leeuwenhoek, utilizando sus simples microscopios de luz, fue el primero en describir, en el siglo XVII, la presencia de microorganismos adhe ridos a superficies dentales, a raíz de lo cual se le reconoce como el descubridor de los biofilms bacterianos ${ }^{1}$. Esta línea de investigación resurgió recién en los '70, cuando Characklis ${ }^{14}$ procedió a estudiar légamos microbianos en sistemas de aguas industriales logrando demostrar su tenacidad y resistencia a diferentes desinfectantes, entre ellos, el cloro. Posteriormente, Costerton y cols ${ }^{15}$ describieron la presencia de comunidades bacterianas embebidas en matriz glucoproteica unidas a superficies en contacto con el agua, postulando que los biofilms podrían ser la explicación para los mecanismos por los cuales los gérmenes se adhieren a superficies vivientes e inertes.

Sin embargo, se debió esperar el advenimiento del microscopio electrónico para lograr un examen detallado de los biofilms. Éste permitió la fotomicroscopía de alta resolución a aumentos significativamente mayores respecto al microscopio de luz. En las últimas dos décadas gran parte del trabajo realizado para la descripción de biofilms se ha basado en la microscopía electrónica de barrido. Mediante ésta se procedió a examinar biofilms en filtros en plantas de tratamiento de aguas servidas, encontrándose que estaban compuestos por una multiplicidad de gérmenes ${ }^{16}$. Usando tinción específica, se logró demostrar que el material de la matriz que engloba a las bacterias en estos biofilms era polisacárido ${ }^{1}$.

Recientemente, dos grandes avances han incrementado substancialmente la comprensión de los biofilms: (a) la utilización del microscopio láser confocal, que ha permitido caracterizar la ultraestructura del biofilm, y (b) la investigación de los genes involucrados en la adhesión celular y la formación de biofilm¹.

\section{COMPOSICIÓN Y ARQUITECTURA}

Toda comunidad microbiana desarrollada en biofilm es única en su género, aunque algunos atributos estructurales pueden, generalmente, ser considerados universales. $\mathrm{日}$ término biofilm es, en cierto modo, un nombre inapropiado, puesto que los biofilms no constituyen un depósito superficial de una monocapa continua! .

Los biofilms están estructurados principalmente por grandes colonias de bacterias sésiles incrustadas en una matriz polimérica extracelular 0 glicocálix. Las células bacterianas, que componen el $15 \%-20 \%$ del volumen, no se dividen al interior de los biofilms, lo cual podría atribuirse al hecho de adoptar un fenotipo alterado, diferente al de las mismas bacterias en estado de libre flotación ${ }^{8}$.

La matriz es muy hidratada debido a que incorpora grandes cantidades de agua dentro de su estructura, llegando este elemento a representar 
hasta el $97 \%$ de ésta 1 . Además de agua y gérmenes, la matriz está formada por exopolisacáridos (EPS), los que constituyen su componente fundamental, producidos por los propios microorganismos integrantes. En menor cantidad se encuentran otras macromoléculas como proteínas, ácidos nucleicos, y diversos productos que proceden de la lisis bacteriana $\mathrm{日}$ conjunto de polisacáridos, ácidos nucleicos y proteínas se conocen bajo el nombre de substancias poliméricas extracelulares (SPE). En la matriz también puede hallarse materiales no bacterianos, tales como cristales de sales minerales, partículas de corrosión y/o de sedimento, o componentes sanguíneos, según sea el medioambiente en el cual se desarrolla el biofilm. Además, los EPS pueden estar asociados con iones metálicos y cationes bivalentes. Pueden tener carga neutra o carga polianiónica, según el tipo de exopolisacárido, lo que les permitiría interactuar con distintos antimicrobianos, de forma tal que estos pueden quedar atrapados en la matriz sin capacidad para actuar sobre las bacterias ${ }^{10}$.

La producción de $\boxminus S$ es influida por la calidad nutricional del medioambiente. Se ha observado que un incremento en la concentración de nutrientes está correlacionado con un aumento en el número de células bacterianas adheridas. Además, unadisponibilidad excesiva de carbono y/o limitación de nitrógeno, potasio o fosfato promueve la síntesis de $\mathrm{PS}^{1,2,9,17}$.

La arquitectura de la matriz no es sólida Las bacterias biofilm viven en torreones celulares que se extienden en forma tridimensional desde la superficie a la cual están adheridas. Estos torreones están compuestos por microcolonias de diferentes células bacterianas, tanto aeróbicas como anaeróbicas, englobadas por exopolisacáridos, y separadas unas de otras por espacios intersticiales huecos, llama dos canales de agua, que permiten el flujo de líquido y actúan como un sistema circulatorio primitivo para el transporte y difusión de nutrientes y oxígeno a las bacterias ubicadas en su interior, incluso aquéllas situadas en las zonas más profundas del biofilm. Asimismo, constituyen un mecanismo para la remoción de productos de desecho metabólico ${ }^{1,18}$.

La existencia de estos canales de agua no impide, sin embargo, que dentro del biofilm se encuentren ambientes en los que la concentración de nutrientes, $\mathrm{pH}$ u oxígeno es diferente. Se gene$\mathrm{ra}$, de esta manera, una gradiente de tensión de $\mathrm{pH}$ y de oxígeno, siendo metabólicamente más activas las áreas superficiales respecto a las más profundas. En estas últimas, las bacterias deben adaptarse a una disponibilidad reducida de oxígeno ${ }^{7,9,18}$.

La formación y estructura de un biofilm depende de las características del substrato al cual se une y a otros aspectos del medio ambiente. Así, los biofilms en una superficie mucosa son fisiológicamente diferentes de aquellos formados en superficies inertes. Se ha acuñado el término "biofilm de mucosa" para describir aquellos que son característicos en mucosas. Estos, aunque estrechamente relacionados con los encontrados en superficies inertes, no son idénticos en cuanto a su expresión génica ni en la naturaleza de sus microambientes. Los biofilms de mucosas son modulados por la respuesta inflamatoria del huésped $y$, además, por proteínas y células del huésped que contribuyen a su composición ${ }^{10}$.

\section{ETAPAS EN EL CICLO VITAL}

La biología de los biofilms se centra en su ciclo vital e interacciones con el medio ambiente. $\mathrm{日}$ ciclo vital es un proceso dinámico que puede ser dividido en 3 partes: adhesión, crecimiento y separación o desprendimiento.

Durante la primera fase, el substrato tiene que ser adecuado para la adsorción reversible y, finalmente, la adhesión irreversible de la bacteria a la superficie. Las bacterias, una vez percibida una superficie, proceden a formar una unión activa vía apéndices, como fimbrias, flagelos o pili. Mediante microscopía electrónica se ha descrito que las bacterias adheridas se encuentran conectadas a la superficie por medio de finas fibrillas poliméricas extracelulares. Las fimbrias, probablemente luego de superar la barrera de repulsión electroestática inicial que existe entre el germen y el sustrato, contribuyen a la adhesión bacteriana ${ }^{1,4}$.

La motilidad, otorgada por flagelos, ayudaría a la bacteria a alcanzar la superficie en las etapas inicia- 
les de la adhesión, siendo su función principal vencer las fuerzas de repulsión más que actuar como adherente. Sin embargo, la motilidad no pareciera ser un requisito esencial, puesto que bacterias Gram positivas inmóviles, como estafilococos, estreptococos y micobacterias, también poseen la capacidad de formar biofilm. En el caso de las bacterias Gram positivas se ha descrito, en esta primera etapa, la participación de proteínas de superficie $e^{6,9}$.

La adhesión de bacterias a una superficie ocurrirá más fácilmente en aquéllas más ásperas, más hidrofóbicas, y recubiertas por "films condicionantes". Se ha descrito que la colonización microbiana parece incrementar a medida que aumenta la aspereza de la superficie. Esto sería debido a que están reducidas las fuerzas de deslizamiento, y el área de superficie se torna mayor². Los films condicionantes, compuestos habitualmente por polímeros, cubren inevitable y rápidamente la superficie de cualquier material que se encuentre en contacto con un líquido, y constituyen requisito indispensable para una ulterior adhesión microbiana. Un buen ejemplo en el hombre puede ser el film conocido como "película adquirida", que se desarrolla en superficies del esmalte dental. Este film consta de albúminas, lisozimas, glicoproteínas, fosfoproteínas, y lípidos. Las bacterias de la cavidad oral colonizan, al cabo de algunas horas, aquellas superficies condicionadas por esta película?.

Las propiedades físico-químicas de la superficie también pueden ejercer una fuerte influencia en el grado y extensión de la adhesión. Se ha encontrado que los gérmenes se adhieren más rápidamente a superficies hidrofóbicas, no polarizadas, como lo es el teflón y otros plásticos, en comparación con materiales hidrofílicos, como vidrio o metales. Aparentemente se produciría algún tipo de interacción hidrofóbica entre la superficie celular y la del sustrato que permitirían a la bacteria superar las activas fuerzas de rechazo a cierta distancia de la superficie del sustrato, y lograr adherirse irreversiblemente ${ }^{1}$.

En la adhesión bacteriana pueden también influir variaciones en la velocidad de flujo, tempera- tura del agua, y concentración de nutrientes. Se ha encontrado que un incremento en la concentración de diversos cationes (sodio, calcio, hierro) afectala adhesión de Pseudomonas spp a superficies de vidrio ${ }^{19}$.

Durante la segunda fase o de crecimiento, la bacteria, una vez adherida, comienza a dividirse y las células hijas se extienden alrededor del sitio de unión, formando una microcolonia, similar al proceso de formación de colonias en placas de agar. A medida que las células se dividen y colonizan la superficie, las bacterias comienzan a elaborar un exopolisacárido que constituye la matriz del biofilm, y éste comienza a desplegarse en una formación tridimensional, generando estructuras similares a setas 5,9 .

La composición del exopolisacárido es diferente para cada bacteria: alginato, en $P$ aeruginosa; celulosa, en $S$ typhimurium; exopolisacárido rico en glucosa y galactosa en $V$. cholerae; poli- $\mathrm{N}$ acetil-glucosamina, en $S$ aureus, etc. Además, estudios recientes señalan que, incluso una misma bacteria, dependiendo de las condiciones ambientales en las que se encuentre, puede producir diferentes exopolisacáridos ${ }^{9}$.

Fnalmente, en la tercera etapa, luego que el biofilm ha alcanzado la madurez, algunas células, ya sea aisladamente o en conglomerados bacterianos, se liberan de la matriz para poder colonizar nuevas superficies, cerrando el proceso de formación y desarrollo del biofilm. $\mathrm{日}$ desprendimiento puede ser resultado de fuerzas externas al biofilm o de proce sos activos inducidos por éste ${ }^{10}$.

Los tres principales mecanismos para generar el desprendimiento serían: (a). erosión o deslizamiento: remoción continua de pequeñas partes del biofilm; (b) separación: remoción rápida y masiva; y (c) abrasión: liberación por colisión de partículas del líquido circundante con el biofilm. La separación es menos frecuente que la erosión, y se piensa derivaría de depleción de nutrientes u oxígeno al interior del biofilm. Se observa preferentemente en biofilms más voluminosos, que se han desarrollado en medioambientes otrora ricos en nutrientes. La separación proporcionaría un mecanismo para que las bacterias migren desde zonas densamente 
colonizadas a áreas que podrían favorecer mejor su desarrollo, logrando así formar nuevos biofilms en sitios distantes. Un ejemplo es la sepsis recurrente en un paciente con un catéter infectado ${ }^{1,6}$.

La forma en que se produce la dispersión afecta ría, aparentemente, las características fenotípicas de los gérmenes. Los conglomerados desprendidos desde el biofilm conservarían, probablemente, ciertas características de éste, tales como la resistencia antimicrobiana En cambio, las células bacterianas liberadas aisladamente podrían rápidamente volver a su fenotipo planctónico, tornándose nuevamentesusceptibles a las defensas del huésped y a los antimicrobianos ${ }^{1}$.

\section{QUORUM SENSING}

Un avance importante en la comprensión de los biofilms ocurrió a comienzos de los '90 con el descubrimiento de proteínas responsables del mecanismo de quorum sensing o de auto-inducción. En los años siguientes se produjo una profusa publicación de nuevos conocimientos acerca de la genética de señalización célula-a-célula y translocación coordinada de genes responsables de factores de defensa y virulencia ${ }^{6,9}$.

La unión de los microorganismos a una superficie y ulterior formación de un biofilm necesita que las bacterias se cercioren que han efectuado contacto. Para lograrlo requieren de señales químicas coordinadas que les permitan comunicarse entre ellas. $\mathrm{日}$ desarrollo de interacciones célularacélula se facilita por la estrecha proximidad existente entre las bacterias biofilm. Esta interrelación, vía mensajeros de pequeñas moléculas, denominada quorum sensing, beneficia a la bacteria al permitirle sentir la presencia de microorganismos vecinos, determinar la densidad de la población existente y responder a eventuales condiciones cambiantes. 日 proceso quorum-sensing funciona debido a que cada bacteria que se une a una superficie produce una molécula señal "yo estoy aqui", de manera tal que mientras más bacterias se unen, se incrementa la concentración local de esta señal. Una vez logrado esto, se inducen diferentes fenómenos en la bacteria, para finalmente gatillarse la diferenciación biofilm. Su objetivo es coordinar determinados comportamientos o acciones entre microorganismos del mismo género, de acuerdo a su número. A menos que esté presente un número adecuado de células bacterianas en la vecindad, los costos de la producción de un biofilm para una bacteria individual superan los beneficios ${ }^{1,3-5,10,20-22}$.

Los gérmenes que utilizan quorum sensing elaboran y secretan moléculas señalizadoras, Ilamados auto-inductores. Las principales moléculas empleadas para comunicarse con las demás bacterias son las acil-homoserina-lactonas, que predominan en bacterias Gram negativas, mientras que oligopéptidos modificados prevalecen en gérmenes Gram positivos. Las bacterias también poseen un receptor que puede detectar específicamente el auto-inductor respectivo. Ouando éste se une al receptor, activa la trascripción de determinados genes, incluyendo aquellos para la síntesis del inductor $^{2,23}$.

Los primeros microorganismos en quienes se observó quorum sensing fueron especies de Myxobacterias y Streptomyces. Sin embargo, el ejemplo más conocido es la regulación de la producción de luz en el Vibrio fischeri, una bacteria bioluminiscente que vive como un simbionte en el órgano generador de luz del calamar hawaiano. Cuando el $V$ fischeri se encuentra en estado planctónico, el auto-inductor está en baja concentración y, de este modo, carece de luminiscencia. En cambio, en el órgano luminoso del calamar están muy concentrados (sobre $10^{11}$ células $/ \mathrm{ml}$ ), induciéndose la trascripción enzimática y generándose bioluminiscencia

日 estudio de esta relación simbiótica comenzó a revelar algunos de los misterios de señales célula-a-célula. En el $V$ fischeri se identificaron dos sistemas quorum-sensing: luxl y luxR. Estos sistemas de señalización se han encontrado en casi todas las bacterias Gram negativas, y moléculas mensajeras célula-a-célula han sido detectados en más de 30 especies de bacterias Gram positivas. Los sistemas lux se han estudiado extensamente en Pseudomonas spp y Escherichia coli, y se les considera necesarios para la maduración del 
biofilm y activación de numerosos genes de factores de virulencia ${ }^{1,12}$.

Davies $^{21}$ demostró que en la formación de biofilm en $P$ aeruginosa están implicados dos sistemas diferentes de señalización célula-a-célula: lasR-lasl y rhIR-rhll. Una vez conseguida una densidad suficiente de población, estas señales alcanzan las concentraciones requeridas para activar los genes implicados en la diferenciación del biofilm. Mutantes incapaces de elaborar ambas señales producen biofilms notoriamente más delgados y sin su arquitectura típica. Además, pueden ser removidos mucho más fácilmente de superficies mediante uso de surfactantes. La adición de lactona homoserina al medio que contiene los biofilms mutantes da origen a biofilms similares a los de bacterias no mutantes ${ }^{1}$.

\section{INTERCAMBIO GÉNICO}

En los últimos años diversos grupos de investigadores han orientado sus esfuerzos intentando identificar tanto los genes responsables de la transición biofilm/planctónica, al igual que aquellos que están expresados únicamente en biofilms y que son indispensables para mantener su particular estructura. Las bacterias biofilms poseen una expresión génica diferente respecto a sus contrapartes planctónicas, originando bacterias fenotípicamente distintas respecto a aquéllas. Se ha encontrado que hasta el $30 \%$ de los genes puede expresarse de manera diferente entre la misma bacteria desarrollada en condiciones planctónicas o en un biofilm $3-5,8,9$.

Los biofilms hospedan un medioambiente muy dinámico, donde se intercambia material genético tal como plásmidos (ácido desoxirribonucleico extra cromosómico), enżmas y otras moléculas ${ }^{3-5}$. Estudios recientes postulan que la matriz de biofilms de $P$ aeruginosa contienen ácido desoxirribonucleico como constituyente principal. Estos estudios, combinados con otros que muestran una tasa de transferencia génica, mediada por plásmidos, enormemente incrementada entre bacterias biofilms, sugieren que la redistribución de genes entre éstas es un proceso continuo con importantes consecuencias en su adaptación evolutiva ${ }^{10}$.

Se ha planteado que cepas bacterianas de importancia clínica unidas a plásmidos desarrollan biofilms más fácilmente. Se ha observado, además, que cepas portadoras de plásmidos transfieren éstos a organismos receptores, generando la formación de biofilm. Sin plásmidos asociados, estos mismos gérmenes producen únicamente microcolonias de escaso desarrollo. Debido a que los plásmidos pueden codificar resistencia a múltiples antimicrobianos, la asociación biofilm proporciona también un mecanismo para selección e incremento de la resistencia bacteriana a los antibióticos ${ }^{1,3-5}$.

\section{RESISTENCIA BACTERIANA}

Las bacterias biofilm presentan una organización estructural que las hace resistentes a los mecanismos de defensa del huésped. Los biofilms, revestidos con SPEy conteniendo múltiples microcolonias bacterianas en su interior, se convierten en estructuras demasiado grandes como para ser fagocitadas, reduciendo la accesibilidad del sistema inmune a las bacterias. Por añadidura, el biofilm provee de una barrera física que aumenta la resistencia de patógenos a las defensas del huésped, como opsonización, lisis por complemento, y fagocitosis $^{10}$.

En rigor, los biofilms provocan respuestas inmunes celular y humoral, demostradas por laidentificación de citoquinas liberadas por leucocitos expuestos a biofilm. Sin embargo, debido a su aislamiento del entorno por la matriz y su reducido estado metabólico, esta respuesta sistémica es muy pequeña'.

Ora ventaja, extremadamente importante desde el punto de vista clínico, es que las bacterias biofilms son muy resistentes a los antibióticos, siendo capaces de sobrevivir frente a concentraciones antibióticas miles de veces mayor respecto a las bacterias planctónicas. Por ejemplo, una cepa de Kebsiella pneumoniae en estado planctónico tiene una concentración inhibitoria mínima de $2 \mu \mathrm{g} / \mathrm{ml}$ ala 
ampicilina Esta misma cepa, al crecer como biofilm, exhibe $66 \%$ de sobrevida luego de terapia con $5.000 \mu \mathrm{g} / \mathrm{ml}$ de ampicilina ${ }^{7,8,11,24}$.

Para intentar explicar esta resistencia se han planteado diversas hipótesis:

(a) Penetración lenta o incompleta del antibiótico en el biofilm: Se debería a que la matriz de exopolisacáridos constituye una barrera impidiendo este ingreso. Si bien estudios in vitro muestran que algunos antibióticos logran ingresar con cierta facilidad, debido a que no existiría una barrera genérica a su difusión a través de la matriz, se postula que si el antibiótico logra ser desactivado en ésta por acción de polímeros extracelulares, puede tener tan sólo una difusión limitada dentro del biofilm ${ }^{10,24}$.

(b) Causas metabólicas: Una baja actividad metabólica de las bacterias biofilm por limitación de oxígeno y nutrientes puede causar que ingresen en un estado de lentificación o cese de su mitosis, especialmente aquéllas situadas más profundamente, con lo cual dejan de ser susceptibles a los antimicrobianos. Además, se ha descrito la formación de nichos anaeróbicos en zonas profundas de biofilms debido a consumo completo del oxígeno en las capas superficiales. Algunos antibióticos, vgr: aminoglicósidos, son comprobadamente menos eficaces contra la misma bacteria en condiciones anaeróbicas que aeróbicas. Fnalmente, una eventual acumulación de productos ácidos en el biofilm puede conducir a diferencias significativas de $\mathrm{pH}$ entre el exterior y el interior de éste, interfiriendo con la acción del antibiótico 10,24.

(c) Cambios genéticos: Se producirían modificaciones en la fisiología de las bacterias biofilm y aparición de genes específicos, producto de cambios genéticos, que potenciarían mecanismos de resistencia a múltiples antibióticos. Según diversos investigadores, esta resistencia se debería principalmente a modificaciones fe notípicas en las bacterias biofilm, las que se rían de tipo protectoras, especialmente al generar cese de la mitosis 2,3,6,8-10. No obstante existir un respaldo mayoritario a esta hipótesis, Stewart y Costerton ${ }^{24}$ expresan sus dudas al respecto, señalando que cuando las bacterias son dispersadas desde un biofilm, con frecuencia se tornan rápidamente susceptibles a antibióticos, lo que sugeriría que tal resistencia no sería adquirida vía mutaciones o elementos genéticamente movibles.

(d) Formación de esporas: Esta hipótesis plantea la posibilidad de génesis de una subpoblación de bacterias biofilm con un estado fenotípico muy especial y altamente protegido, con una diferenciación símil esporas. Este planteamiento es apoyado por investigaciones que muestran resistencia en biofilms recientemente formados, aun cuando estos son demasiado delgados para constituir una barrera a la penetración de agentes antimicrobianos ${ }^{24}$.

Es preciso tener presente que los antibióticos utilizados rutinariamente en clínica han sido seleccionados por su actividad frente a bacterias planctónicas. Lo anterior debido a que los estudios de sensibilidad o antibiogramas que se realizan habitualmente están diseñados para medir la susceptibilidad de la bacteria crecida de forma planctónica, sin tener en cuenta que los resultados obtenidos pueden no extrapolarse a esa misma bacteria cuando lo hace en el interior de un biofilm. Las mismas propiedades que hacen a las bacterias biofilms resistentes a antibióticos y al sistema inmune, también las tornan difíciles de cultivar in vitro. Incluso, su estado metabólico dentro del biofilm puede imposibilitar por completo su cultivo 9,10 .

\section{BIOFILMS E INFECCIONES}

Las enfermedades infecciosas durante el siglo pasado eran causadas por bacterias dotadas de mecanismos patogénicos específicos: difteria, tuberculosis, cólera, coqueluche, etc. Los antibióticos y vacunas desarrollados para estos gérmenes lograron una notable eficacia en su control. En la actualidad estas bacterias han sido desplazadas del primer plano por microorganismos ubicuos, capaces de producir infecciones 
de tipo crónico, que responden pobremente a los tratamientos antibióticos y no pueden prevenirse mediante inmunización. Diversas publicaciones re cientes señalan que, por lo menos, el $65 \%$ de todos los procesos infecciosos bacterianos humanos podrían involucrar biofilms $3-5,7,9,22$.

En los últimos 10 años, debido a su prevalencia abrumadora, los biofilms han sido reconocidos progresivamente como factores importantes en la patogenia de muchas infecciones humanas persistentes, incluyendo placa dental, caries, infección periodontal, neumonía por Pseudomona en fibrosis quística, cistitis crónica, endocarditis bacteriana, osteomielitis, y prostatitis crónica. También se ha demostrado que una variedad de dispositivos médicos implantables pueden portar biofilms, provocando infecciones asociadas, destacando la sepsis por catéteres endovenosos y arteriales. Además se han descrito en catéteres urinarios, sigmoidoscopios, y lentes de contacto. Constituyen, también, un problema serio en válvulas cardíacas artificiales, marcapasos y prótesis ortopédicas las cuales, una vez infectadas, generan infecciones excepcionalmente difíciles de resolver mediante antibióticos ${ }^{1,3,6,8,10,12,25}$.

Desde los años ' 70 se ha documentado la acumulación bacteriana en tubos endotraqueales en unidades de Ouidado Intensivo. La presencia de biofilms Gram negativos en estos tubos ha sido relacionada con neumonía intrahospitalaria, presumiblemente por diseminación mecánica durante la aspiración ${ }^{26,27}$. Un reciente estudio, usando microscopía láser confocal, logró identificar biofilms bacterianos en 10 de 11 tubos de traqueostomía pediátricos ${ }^{6}$.

La naturaleza de la placa dental comenzó a adquirir gran importancia a partir de los mediados de los '60, poniéndose énfasis en los factores contribuyentes a la diversidad de ecosistemas, incluyendo $\mathrm{pH}$, potencial de oxido-reducción y requerimientos nutricionales ${ }^{2}$.

Intentando explicar la progresión de la enfermedad dental se ha propuesto una hipótesis de placa inespecífica y otra, de placa específica Se gún la primera, la enfermedad periodontal sería el resultado de la elaboración de productos nocivos por toda la flora microbiana de la placa. Así, una gran acumulación de placa produciría cantidades importantes de substancias perjudiciales, las cuales superarían las defensas del huésped, generando enfermedad periodontal. Al desarrollo de ésta contribuirían todos los gérmenes al interior de la placa, no siendo importante identificar un germen aislado. Por ende, las medidas de higiene oral, buscando remover tanta placa dental como fuera posible, se hicieron imprescindibles para la conservación de la salud oral2,28.

En cambio, la hipótesis de placa específica postula que sólo ciertos gérmenes dentro de la placa serían patógenos, y que el grado de daño dependería de un crecimiento excesivo o selección de las bacterias más virulentas. Según esta teoría, la enfermedad periodontal sería el resultado de noxas celulares causadas por patógenos específi$\cos$, las que provocarían respuestas inflamatorias e inmunes por el huésped?2

En Aorrinolaringología, aunque existe escasa literatura respecto a la participación de los biofilms en enfermedades localizadas en esta área, gradualmente se está evidenciando que los biofilms poseerían un rol importante en derrame crónico en oído medio, amigdalitis crónica, sinusitis crónica, colesteatoma, e infecciones asociadas a dispositivos, tales como tubos de timpanostomía, prótesis vocales y tubos endotraqueales $3-8,10,13,29-32$. Pawlowski y cols ${ }^{33}$, en 2005, notificaron la presencia de biofilm bacteriano en un implante coclear humano.

Los tubos de timpanostomía son quizás los dispositivos de material foráneo más frecuentemente implantados en humanos. Se ha estudiado con microscopía, tanto electrónica como láser confocal, las influencias que la superficie y las propiedades físicas del material tienen en la formación de biofilm. Experimentos efectuados con $P$ aeruginosa y $S$ aureus han encontrado que las superficies lisas (vgr: silicona y plástico tetrafluoruro) son menos propensas al desarrollo de biofilm 34,35 .

日 comportamiento de los patógenos en otitis media aguda se ajusta bastante bien con los principios microbiológicos clásicos: las bacterias son cultivables en la mayoría de los casos, y la terapia antimicrobiana tiene un efecto significativo en los 
síntomas clínicos. En cambio, en otitis media con derrame el comportamiento de patógenos no es tan claro. Los cultivos a menudo no muestran desarrollo, la terapia antibiótica posee escaso o nulo efecto en la resolución, y la duración de la enfermedad es, con frecuencia, prolongada. Las evidencias respecto a la formación de biofilm en derrame crónico de oído medio están comenzando a arrojar luces en muchos de estos misterios ${ }^{6}$.

Hall-Stoodley y cols ${ }^{36}$ detectaron presencia de biofilms en $92 \%$ de muestras de mucosa oído medio, examinadas con microscopio láser confocal, de 26 niños portadores de otitis media con derrame y otitis media recurrente, estructuras que no se observaron en las muestras de 8 pacientes controles.

En el pasado se ha identificado ácido desoxirribonucleico bacteriano en derrames de oído medio con cultivos negativos. Sin embargo, permanecen interrogantes respecto a la viabilidad y carácter patógeno de estas bacterias. Estudios recientes respecto a ARN mensajero bacteriano y endotoxinas bacterianas en derrames de oído medio sin cultivos positivos implican a biofilms en la patogénesis de estas infecciones. Si los biofilms están involucrados en enfermedad crónica de oído medio, es lógico presumir que ellos también podrían participan en otras enfermedades crónicas respiratorias altas, tales como amigdalitis, sinusitis, y adenoiditis 6,19 .

Chole y cols ${ }^{8}$ encontraron biofilms en el interior de criptas en 11 de 15 tonsilas infectadas crónicamente. Las bacterias biofilms, así protegidas de las defensas del huésped y de los antibióticos, continuarían metabolizando y formando endotoxinas. Lo anterior puede conducir a una inflamación crónica. arando las condiciones medioambientales locales fuesen eventualmente favorables, estas bacterias podrían hacerse móviles, determinando que se repita una infección aguda.

La rebeldía de la rinosinusitis crónica (RSC) es compatible con el perfil de una infección por biofilm. Oryer y cols ${ }^{37}$ fueron los primeros en informar sobre la presencia de biofilms en pacientes quienes habían sido intervenidos quirúrgica- mente, y continuaban presentando síntomas a pesar de tratamiento médico. Estos enfermos tenían, principalmente, infección por $P$ aeruginosa. Ramadan ${ }^{4}$ mediante el empleo de microscopía electrónica de barrido encontró evidencias de biofilms en todas las biopsias de mucosa en cinco pacientes quienes habían sido intervenidos quirúrgicamente por RSC.

En un estudio posterior, este autor realizó una investigación prospectiva controlada en 30 pacientes. Las muestras tisulares fueron obtenidas de senos enfermos, específicamente mucosa etmoidal. 日 examen de las 30 muestras detectó evidencias de biofilms en 24 (80\%) de los sujetos. En cambio, los controles tenían cilios y células caliciformes de aspecto saludable, sin presencia de biofilms ${ }^{5}$.

Investigaciones efectuadas respecto a cambios de la mucosa en rinosinusitis crónica revelan diferentes grados de denudación, generando superficies con muchas de las características requeridas para la formación de un biofilm, incluyendo: aspereza de la superficie, hidrofobicidad, sodio, calcio, iones férricos, abundante suministro de nutrientes, y temperatura adecuada $3,4,38$.

日 exacto papel de los biofilms bacterianos en RSC aún permanece por aclararse. Se postula que, en la etiología de esta enfermedad, la mutación de las bacterias biofilm -fenotípicamente diferentes de las formas planctónicas- sería de mayor importancia que la resistencia de la matriz del biofilm a la penetración antibiótica. Adicionalmente, debido a esta resistencia al tratamiento, las bacterias biofilm se convertirían en reservorios para el establecimiento de infecciones sinusales crónicas ${ }^{7,39}$.

\section{ESTRATEGIAS TERAPÉUTICAS FUTURAS}

日 reconocimiento que el biofilm es responsable de un grupo significativo de enfermedades humanas posibilita la búsqueda de enfoques novedosos para el tratamiento y prevención, como podría ser el inhibir la adhesión mediante la alteración de la superficie. Una alternativa para disminuir la fijación a superficies incluye uso de agentes quelantes, que limitan el hierro, el cual es necesario para la 
adhesión de los pili de Pseudomonas $s p^{40}$. 日 xilitol, un alcohol natural del azúcar administrado bajo la forma de jarabe o goma de mascar, ha mostrado una efectividad clínica significativa en prevenir caries y disminuir la incidencia de otitis media en niños, posiblemente vía reducción de mecanismos de adhesión bacteriana ${ }^{41}$.

Debido a que la resistencia que presenta el biofilm depende de la agregación de bacterias en comunidades multicelulares, una estrategia puede ser desarrollar terapias que rompan su estructura multicelular. Si la multicelularidad del biofilm es derrotada, las defensas del huésped pueden ser capaces de resolver la infección logrando, de esta manera, restituir la eficacia de los antibióticos. Terapias potenciales incluyen enzimas que disuelvan los polímeros de la matriz, reacciones químicas que bloqueen la síntesis de la matriz del biofilm y el empleo de análogos de proteínas y péptidos señalizadores que interfieran con la comunicación célula-a-célula, indispensables para la formación de un biofilm 23,24 .

Se ha demostrado que los antibióticos macrólidos parecen inhibir la síntesis de polisacáridos y, de esta manera, degradarían la protección de la superficie del biofilm. Estos antimicrobianos podrían tener un efecto inmunomodulador logrando impedir señales bacterianas. $日$ tratamiento de biofilms con claritromicina reduce la matriz que cubre el biofilm, tanto de $P$ aeruginosa como de $S$ epidermidis, aunque las bacterias mismas sean resistentes al antibiótico ${ }^{10,42}$.

Fnalmente, otras dos estrategias promisorias son cambios en el medioambiente a través de inhibición competitiva por otras bacterias (vgr: estreptococos alfa) o incremento de la tensión de oxígeno (vgr: en pacientes con tubos de timpanostomía) ${ }^{6}$.

Se ha identificado una molécula denominada "furanona", producida por el alga Delisea pulcra, con una estructura similar a las acil-homoserinalactonas. Estas moléculas bloquean el sistema quorum sensing y la consiguiente formación de biofilm. En la actualidad se intenta desarrollar inhibidores de la formación de biofilm basados en derivados de la furanona, ya que esta molécula es extremadamente tóxica ${ }^{43}$.

\section{BIBLIOGRAFÍA}

1. DONLAN RM. Biofilms: Microbial life on surfaces. Emerg Infect Dis 2002; 8 (9): 881-90.

2. THOMAS JG, NAKAISH LA. Managing the complexity of a dynamic biofilm. J Am Dent Assoc 2006; 137(suppl): 10S-15S.

3. Sanclement Ja, Wemster Pl, thomas J, RamaDAN HH. Bacterial biofilms in surgical specimens of patients with chronic rhinosinusitis. Laryngoscope 2005; 115: 578-82.

4. Ramadan HH, Sanclgment, JA, ThOMas JG Chronic rhinosinusitis and biofilms. Otolayngol Head Neck Surg 2005; 132: 414-7.

5. RAMADAN HH. Chronic rhinosinusitis and bacterial biofilms. Ourr Opin Otolaryngol Head Neck Surg 2006; 14(3): 183-6

6. SoOTt C, MANNING SC. Basics of biofilm in clinical otolaryngology. Ear Nose Throat $J$ 2003; 82 (suppl): 18-20.

7. SANDeRson AR, Led JG, HunsaKer D. Bacterial biofilms on the sinus mucosa of human subjects with chronic rhinosinusitis. Laryngoscope 2006; 116: 1121-6.

8. GHOLE RA, FADDIS BT. Anatomical evidence of microbial biofilms in tonsillar tissues: A possible mechanism to explain chronicity. Arch Otolaryngol Head Neck Surg 2003; 129: 634-6.

9. Lasa I, de Pozo JL, PenadÉs JR, Leva J. Biofilms bacterianos. www.cfnavarraes/salud/ anales/textos/vol28/n2/

10. POST JC, StOODLEY P, HALL-STOODLEY L, EHRLICH GD. The role of biofilms in otolaryngologic infections. Ourr Ooin Otolaryngol Head Neck Surg 2004; 12: 185-90.

11. ANDERL JN, FRANKLIN MJ, STEWART PS. Role of antibiotic penetration limitation in Kebsiella pneumoniae biofilm resistance to ampicillin and ciprofloxacin. Antimicrob Agents Chemother 2000; 44: 1818-24.

12. COStgrton JW, StewARt PS, GR⿴NBerg EP. Bacterial biofilms: A common cause of persis- 
tent infections. Science 1999; 284: 1318-22.

13. Frgie N, Bayston R, Pearson J, BirChall J. Is otitis media with effusion a biofilm infection? Cin Aolaryngol 2004; 29: 38-46.

14. CHARACKLIS WG citado por (1).

15. COSterton JW, GeESEY GG, OHeng KJ. How bacteria stick. Sci Am 1978; 238: 86-95.

16. JONES HC, ROTH IL, SAUNDERS WM III. Eectron microscopic study of a slime layer. J Bacteriol 1969; 99: 316-25.

17. SUTHERLAND IW. Biofilm exopolysaccharides: a strong and sticky framework. Microbiology 2001; 147: 3-9.

18. De B巴R D, StOOdLey P, RoE F et Al. Effects of biofilm structure on oxygen distribution and mass transport. Biotechnol Bioeng 1994; 43: 1131-8.

19. Fletaher M. Attachment of Pseudomonas fluorescens to glass and influence of electrolytes on bacterium-substratum separation distance. J Bacteriol 1988; 170: 2027-30.

20. Singh P, Schaettr A, Parsek M et al. Quorum sensing signals indicate that cystic fibrosis lungs are infected with bacterial biofilms. Nature2000; 407: 762-4.

21. Davies DG, Parsek MR, Pearson JP, IGlewSKI BH, COSTERTON JW, GRENBERG E. The involvement of cell-to-cell signals in the development of a bacterial biofilm. Science 1998; 280: 295-8.

22. POTERA C. Forging a link between biofilms and disease. Science 1999; 283: 1837-9.

23. COLÓN-GONZÁlEZ MT, MeMBRILLO-HERNÁNDEZ J. Comunicación entre bacterias. http://www. microbiologia.org.mx/ microbiosenlinea / CAPITULO 04/Capitulo04.pdf

24. SteWART PS, COSTERTON JW. Antibiotic resistance of bacteria in biofilms. Lancet 2001; 358: 135-8.

25. Costriton JW. Oystic fibrosis pathogenesis and the role of biofilms in persistent infection. Trends Microbiol 2001; 9: 50-2.

26. FeldMan C, KaSSE M, CANTREL J ET AL. The presence and sequence of endotracheal tube colonization in patients undergoing mechanical ventilation. Eur Respir J 1999; 13: 546-51.
27. Sotmle fD, Marrie tJ, Prough dS et al. Nosocomial pulmonary infection: Possible etiologic significance of bacterial adhesion to endotracheal tubes. Crit Care Med 1986; 14 : 265-70.

28. LOESCHE WJ. Chemotherapy of dental plaque infections. Oral Sci Rev 1976; 9: 65-107.

29. CHOLE RA, FADDIS BT. Evidence for microbial biofilms in cholesteatomas. Arch Oolaryngol Head Neck Surg 2002; 128: 1129-33.

30. RAYNER MG, ZHANG Y, GORRY MC, OHeN Y, POST JC, EHRLICH GD. Evidence of bacterial metabolic activity in culture negative otitis media with effusion. JAMA 1998; 279: 296-9.

31. EHRLICH GD, V巴⿴囗十 R, WANG X ET AL. Mucosal biofilm formation on middle-ear mucosa in the chinchilla model of otitis media JAMA 2002; 287: 1710-5.

32. Post JC. Direct evidence of bacterial biofilms in otitis media. Laryngoscope 2001; 111: 208394.

33. PAWLOWSKI KS, WAWROD, ROLAND PS. Bacterial biofilm formation on a human cochlear implant. Otol Neurotol 2005; 26: 972-5.

34. SAIDI IS, BIELINGMAIER JF, WHEAN P. In vivo resistance to bacterial biofilm formation on tympanostomy tubes as a function of tube material. Aolaryngol Head Neck Surg 1999; 120: 621-7.

35. Biglingmaigr JF, Samaranayake R, Whean P. Resistance to biofilm formation on otologic implant materials. Atolaryngol Head Neck Surg 1998; 118: 444-51.

36. Hall-Stoodley L, Ze Hu F, Geseke A, Nisti@ L ET AL. Direct detection of bacterial biofilms on the middle-ear mucosa of children with chronic otitis media. JAMA 2006; 296: 202-11.

37. CRYgr J, SCHIPOR I, Perloff JR, PALMer JN. Evidence of bacterial biofilms in human chronic sinusitis. ORL J Otorhinolaryngol Relat Spec 2004; 66: 155-8.

38 BIEDLINGMAIER JF, TRIFLLIS A. Comparison of CT scan and electron microscopic findings on endoscopically harvested middle turbinates. Otolaryngol Head Neck Surg 1998; 118: 165-73. 
39. OHAN J, HADLEY J. The microbiology of chronic rhinosinusitis: Results of a community surveillance study. Ear Nose Throat J2001; 80: 143-5.

40. Singh PK, ParseK MR, GR⿴囗十⺝BERG $巴$, We MJ. A component of innate immunity prevents bacterial biofilm development. Nature 2002; 417: 552-5.

41. UHARI M, KontIOKARI T, NieMEA M. A novel use of xylitol sugar in preventing acute otitis media. Pediatrics 1998; 102 (Pt 1): 879-84.
42. YASUDA H, AlIKI Y, KOGA T, ET AL. Interaction between biofilms formed by Pseudomonas aeruginosa and clarithromycin. Antimicrob Agents Chemother 1993; 37: 1749-55.

43. HeNIZER M, RIEDE K, Rasmussen tB et al. Inhibition of quorum sensing in Pseudomonas aeruginosa biofilm bacteria by a halogenated furanone compound. Microbiology 2002; 148 (Pt 1): 87-102. 